\title{
ANALISIS PERKEMBANGAN PELAKSANAAN PEMBAYARAN BEA PEROLEHAN HAK ATAS TANAH DAN BAGUNAN TERHADAP JUAL BELI TANAH
}

\author{
Haedar Hakim Husainy, Budi Ispriyarso, Novira Maharani Sukma \\ Program Studi Magister Kenotariatan \\ Fakultas Hukum, Universitas Diponegoro \\ Email: haedarhakimhusainy@gmail.com
}

\begin{abstract}
The local government of Pekalongan City in collaboration with the regional bank launched an online tax payment service application including the BPHTB tax. The service makes taxpayers, PPAT, and BKD officers do not need to face-to-face, in order to prevent any leakage that has been experienced so far because several parties have cooperated so that the paid BPHTB tax becomes cheap even though it is not in accordance with the transaction price that occurs in field. This research is an empirical juridical research. The research specifications in this study are analytical descriptive. Data sources are field and library research. The development of BPHTB implementation on the sale and purchase of land and buildings in Pekalongan City, namely before the E-BPHTB service is available, the PPAT must come to the office of the regional financial agency to arrange the files and payments, but after the E-BPHTB services make the process faster, easy, efficient and economical. The obstacles that occur in the implementation of E-BPHTB are the changing value benchmark rules, validation takes a long time if the proposed value is rejected by BKD and there are still dishonest taxpayers providing information about the actual value of the transaction in the field.
\end{abstract}

Keyword : tax; BPHTB; buy and sell

\begin{abstract}
Abstrak
Pemerintah daerah Kota Pekalongan bekerja sama dengan bank daerah meluncurkan aplikasi layanan pembayaran pajak secara online termasuk didalamnya pajak BPHTB. Layanan tersebut menjadikan wajib pajak, PPAT, dan petugas BKD tidak perlu bertatap muka langsung, guna mencegah adanya kebocoran yang selama ini di alami karena beberapa pihak melakukan suatu kerja sama agar pajak BPHTB yang di bayarkan menjadi murah meskipun tidak sesuai dengan harga transaksi yang terjadi di lapangan. Penelitian ini merupakan penelitian yang bersifat yuridis empiris. Spesifikasi penelitian dalam penelitian ini adalah deskriptif analitis. Sumber data yaitu penelitian lapangan dan pustaka. Perkembangan pelaksanaan BPHTB terhadap jual beli tanah dan bangunan di Kota Pekalongan yaitu sebelum adanya layanan E-BPHTB, pihak PPAT harus datang ke kantor badan keuangan daerah untuk melakukan pengurusan berkas dan pembayaran, akan tetapi setelah adanya layanan E-BPHTB menjadikan prosesnya menjadi lebih cepat, mudah, efisien dan hemat. Hambatan-hambatan yang terjadi dalam pelaksanaan E-BPHTB yaitu aturan patokan nilai yang berganti-ganti, validasi menjadi lama apabila nilai yang diajukan ditolak BKD serta masih adanya wajib pajak yang tidak jujur memberikan informasi tentang nilai traksaksi yang sebenarnya di lapangan.
\end{abstract}

Kata kunci : Pajak ; BPHTB ; jual beli 


\section{A. Pendahuluan}

Pada era globalisasi yang millenial sekarang ini, pelaksanaan pembangunan nasional merupakan salah satu cara untuk mencapai terwujudnya pelaksanaan otonomi dan meningkatkan pertumbuhan ekonomi agar diharapkan semakin meningkat, serta dapat mensejahterakan penduduknya. Salah satunya melalui pajak, Pajak itu sendiri menurut Soeparman Soemahamidjaja merupakan iuran wajib, berupa uang atau barang yang dpungut oleh penguasa berdasarkan norma-norma hukum guna menutup biaya produksi baran dan jasa kolektif dalam mencapai kesejahteraan umum.(Sutedi, 2008) Semenjak diberlakukannya undang-undang otonomi daerah yaitu yaitu undang-undang nomor 22 tahun 1999 jo undangundang nomor 32 tahun 2004 jo Undang-undang nomor 12 tahun 2008 jo undang-undang nomor 23 tahun 2014 sebagaimana telah diubah terakhir Undang-Undang Nomor 9 tahun 2015 tentang otonomi daerah.

Kewenangan daerah dalam hal fiskal tersebut diwujudkan oleh daerah dengan memungut salah satu potensi pendapatan daerah yaitu berasal dari pajak daerah sebagaimana diatur dalam Undang-Undang Nomor 28 tahun 2009 tentang Pajak Daerah dan Retribusi Daerah. Undangundang tersebut mengamanatkan bahwa salah satu jenis pajak kabupaten/kota adalah Pajak Bea Perolehan Hal atas Tanah dan Bangunan (BPHTB), yang menggunakan Nilai Perolehan Objek Pajak (NPOP) sebagai dasar pengenaan pajak tersebut.(Widayat, 2016)

Tujuan BPHTB adalah: "Perlunya diadakan pemungutan pajak atas Perolehan Hak Atas Tanah dan Bangunan, sebagaimana telah pernah dilaksanakan dan dilakukan sebagai upaya kemandirian bangsa untuk memenuhi pengeluaran pemerintah berkaitan dengan tugasnya dalam menyelenggarakan pemerintahan umum dan pembangunan”.(Siahaan, 2003)

Salah satu objek pajak BPHTB yakni dengan pemindahan hak karena adanya jual beli. Transaksi jual beli tanah dan/atau bangunan merupakan suatu aktivitas yang dilakukan oleh masyarakat yang dapat memberikan pemasukan berupa pajak dalam jumlah yang relatif besar bagi daerah. Karena jual beli merupakan suatu perbuatan hukum yang dapat menimbulkan hutang pajak.(ispriyarso, 2005)

Di Kota Pekalongan, BPHTB diatur dalam Peraturan Daerah Kota Pekalongan Nomor 08 Tahun 2010 tentang BPHTB dan Peraturan Walikota Nomor 35 Tahun 2010 tentang sistem dan prosedur pemungutan BPHTB. BPHTB menurut UU Nomor 28 Tahun 2009 tetang Pajak Daerah dan Retribusi daerah dalah pajak yang perolehan hak atas tanah dan atau bangunan. Menurut ketentuan Pasal 5 Peraturan Daerah Kota Pekalongan Nomor 8 Tahun 2010 mengatakan bahwa dasar pengenaan BPHTB adalah NPOP. NPOP (Nilai Perolehan 
Objek Pajak) tersebut apabila tidak diketahui atau lebih rendah dari NJOP yang digunakan dalam pengenaan PBB, maka dasar pengenaannya yang dipakai NJOP PBB, serta dalam Pasal 6 perda tersebut, menyebutkan tarif pengenaan BPHTB di tetapkan sebesar $5 \%$.

Pada Akhir Tahun 2018, Pemerintah daerah Kota Pekalongan dalam hal ini Badan Keuangan Daerah bekerja sama dengan Bank Jateng meluncurkan sebuah aplikasi layanan pembayaran pajak secara online termasuk didalamnya pajak bea perolehan hak atas tanah dan bangunan. Layanan tersebut menjadikan wajib pajak, PPAT, dan petugas BKD tidak perlu bertatap muka langsung, guna mencegah adanya kebocoran yang selama ini di alami karena beberapa pihak melakukan suatu kerja sama agar pajak BPHTB yang di bayarkan menjadi murah meskipun tidak sesuai dengan harga transaksi yang terjadi di lapangan.

Berkaitan dengan adanya sistem pembayaran BPHTB secara online tersebut, di perkuat dengan adanya Peraturan Walikota Pekalongan Nomor 29 Tahun 2018 tentang pelaksanaan sistem online pajak daerah Pasal 2 huruf $\mathrm{f}$ mengenai jenis pajak yang diatur oleh walikota yaitu BPHTB. Kewenangan dalam melakukan pengelolaan sistem online tersebut diatur oleh walikota yang selanjutnya dilimpahkan kepada Kepala Badan Keuangan Daerah, sesuai dengan Pasal 3 perwal tersebut.akan tetapi dalam pelaksanaannya masih tedapat persoalan yang sama yang timbul di masyarakat,khususnya wajib pajak yakni mengenai hasil verifikasi BKD dalam menentukan NPOP atas peralihan hak atas tanah akibat perbuatan hukum jual beli yang mana berdasarkan harga transaksi atau nilai pasar. Contohnya banyaknya masyarakat yang ingin di turunkan nilai transaksi nya karena keberatan dengan hasil verifikasi BKD yang dianggap terlalu tinggi, dan mengakibatkan para pihak kerja sama dengan PPAT. Berdasarkan hal tersebut artinya bahwa informasi yang di sampaikan kepada BKD tersebut datanya bukanlah data yang sebenarnya yang terjadi di lapangan. Sehingga mengakibatkan penerimaan pajak asli daerah menjadi kurang maksimal.

Berdasarkan dari uraian dalam latar belakang tersebut, maka dapat dirumuskan pokok permasalahan yang akan menjadi fokus utama, adalah sebagai berikut : Bagaimana perkembangan pelaksanaan pembayaran BPHTB terhadap jual beli ha katas tanah dan bangunan di Kota Pekalongan? Hambatan-hambatan apa saja yang timbul dari pelaksanaan EBPHTB tersebut?

\section{Teori Kebijakan Publik}

Pendefinisian mengenai kebijakan diperlukan agar kita dapat menjaga kejelasan pemikiran kita dalam pembahasan selanjutnya. Kebijakan adalah salah satu konsep dalam ilmu politik.1 Kebijakan (policy) adalah suatu kumpulan keputusan yang diambil oleh 
seorang pelaku atau kelompok politik, dalam usaha memilih tujuan dan cara untuk mencapai tujuan itu. Pada prinsipnya, pihak yang membuat kebijakan-kebijakan itu mempunyai kekuasaan untuk melaksanakan.(Budiardjo, 2009)

Harold D. Lasswell dan Abraham Kaplan mengartikan kebijaksanaan sebagai a projecterd program of goals, values and practice yang artinya adalah suatu program pencapaian tujuan, nilai-niai dan praktek-praktek yang terarah. Sedangkan penjelasan lain mengenai kebijakan publik adalah serangkaian tindakan yang di usulkan seseorang, kelompok atau pemerintah dalam suatu lingkungan tertentu dengan menunjukkan hambatan-hambatan dan kesempatankesempatan terhadap pelaksanaan usulan kebijaksanaan tersebut dalam rangka mencapai tujuan tertentu.(Islamy, 2000)

Menurut Woll, Kebijakan Publik adalah sejumlah aktivitas pemerintah untuk memcahkan masalah di masyarakat baik secara langsung mauPun melalui berbagai lembaga yang mempengaruhi kehidupan masyarakat. Sedangkan James E. Anderson memberikan definisi kebijakan Publik sebagai kebijakan - kebijakan yang dibangun oleh badan - badan dan pejabat - pejabat pemerintah, dimana implikasi dari kebijakan itu adalah : (Tangkilisan, 2003)

1. kebijakan Publik selalu memPunyai tujuan tertentu atau memPunyai tindakan tindakan yang berorientasi pada tujuan;

2. kebijakan Publik berisi tindakan pemerintah;

3. kebijakan Publik merupakan apa yang benar - benar dilakukan oleh pemerintah, jadi bukan merupakan apa yang masih dimaksudkan untuk dilakukan;

4. kebijakan Publik yang diambil bisa bersifat positif dalam arti merupakan tindakan pemerintah mengenai segala sesuatu masalah tertentu atau bersifat negatif dalam arti merupakan kePutusan pemerintah untuk tidak melakukan sesuatu;

5. kebijakan pemerintah setidak - tidaknya dalam arti yang positif didasarkan pada peraturan perundangan yang bersifat mengikat dan memaksa.

\section{Teori Kepastian Hukum}

Kepastian adalah perihal (keadaan) yang pasti, ketentuan atau ketetapan. Hukum secara hakiki harus pasti dan adil. Pasti sebagai pedoman kelakukan dan adil karena pedoman kelakuan itu harus menunjang suatu tatanan yang dinilai wajar. Hanya karena bersifat adil dan dilaksanakan dengan pasti hukum dapat menjalankan fungsinya. Kepastian hukum merupakan pertanyaan yang hanya bisa dijawab secara normatif, bukan sosiologi.(Rato, 2010) 
Menurut Kelsen, hukum adalah sebuah sistem norma. Norma adalah pernyataan yang menekankan aspek "seharusnya" atau das sollen, dengan menyertakan beberapa peraturan tentang apa yang harus dilakukan. Norma-norma adalah produk dan aksi manusia yang deliberatif. Undang-Undang yang berisi aturan-aturan yang bersifat umum menjadi pedoman bagi individu bertingkah laku dalam bermasyarakat, baik dalam hubungan dengan sesama individu maupun dalam hubungannya dengan masyarakat. Aturan-aturan itu menjadi batasan bagi masyarakat dalam membebani atau melakukan tindakan terhadap individu. Adanya aturan itu dan pelaksanaan aturan tersebut menimbulkan kepastian hukum.(Marzuki, 2008)

Kepastian hukum secara normatif adalah ketika suatu peraturan dibuat dan diundangkan secara pasti karena mengatur secara jelas dan logis. Jelas dalam artian tidak menimbulkan keragu-raguan (multi tafsir) dan logis. Jelas dalam artian ia menjadi suatu sistem norma dengan norma lain sehingga tidak berbenturan atau menimbulkan konflik norma. Kepastian hukum menunjuk kepada pemberlakuan hukum yang jelas, tetap, konsisten dan konsekuen yang pelaksanaannya tidak dapat dipengaruhi oleh keadaankeadaan yang sifatnya subjektif. Kepastian dan keadilan bukanlah sekedar tuntutan moral, melainkan secara factual mencirikan hukum. Suatu hukum yang tidak pasti dan tidak mau adil bukan sekedar hukum yang buruk.(Cst Kansil, Christine, S.T Kansil, Engelien R, 2009)

Dalam penulisan ini, belum terlihat adanya kepastian hukum dalam hal penentuan harga transaksi jual beli dalam pemungutan BPHTB yang dilaporkan secara online oleh para pihak yang telah sepakat melaksanakan jual beli kepada Badan Keuangan daerah Kota Pekalongan, dan apakah verifikasi yang dilakukan BKD Kota Pekalongan secara online itu bisa di pertanggung jawabkan kesesuaian data yang di sampaikan oleh para pihak.

\section{a. Kebaruan/Orisinalitas Hasil Penelitian}

1. Aspek Perpajakan dalam Pengalihan Hak Atas Tanah dan/atau Bangunan karena Adanya Transaksi Jual Beli. Jurnal ini membahas tentang prosedur pengalihan ha katas tanah dan/atau bangunan karena adanya transaksi jual beli di lihat dari aspek perpajakannya yaitu Bea Perolehan Hak Atas Tanah dan Bangunan (BPHTB)(ispriyarso, 2005)

2. Analisis Pengenaan Bea Perolehan Hak Atas Tanah Dan Bangunan Dalam Proses Jual Beli Tanah Dan Bangunan Di Kabupaten Kebumen. Jurnal ini membahas tentang pelaksanaan pemungutan Bea Perolehan Hak Atas Tanah dan Bangunan dalam proses jual beli tanah dan bangunan di Kabupaten Kebumen ,kendala-kendala apa yang timbul 
dalam pelaksanaan pemungutan bea perolehan hak atas tanah dan bangunan dan penyelesain terhadap kendala-kendala yang timbul dalam pelaksanaan pemungutan bea perolehan hak atas tanah dan bangunan dalam proses jual beli tanah dan bangunan di Kabupaten Kebumen.(Widayat, 2016)

\section{B. Metode Penelitian}

Penelitian ini merupakan penelitian yang bersifat yuridis empiris. Pendekatan yuridis empiris yaitu cara prosedur yang dipergunakan untuk memecahkan masalah penelitian dengan meneliti data sekunder terlebih dahulu untuk kemudian dilanjutkan dengan mengadakan penelitian terhadap data primer di lapangan(Soekanto, 1985). Spesifikasi penelitian dalam penelitian ini adalah deskriptif analitis, yaitu penelitian yang bertujuan untuk menggambarkan keadaan dari suatu obyek atau masalah yang akan diteliti secara sistematis tanpa bermaksud mengambil kesimpulan yang sifatnya umum.(Soemitro, 1988).

\section{Hasil Penelitian Dan Pembahasan}

\section{Perkembangan Pelaksanaan Pembayaran BPHTB terhadap Jual Beli Hak Atas Tanah dan Bangunan di Kota Pekalongan}

Pada Akhir Tahun 2018, Pemerintah daerah Kota Pekalongan dalam hal ini Badan Keuangan Daerah bekerja sama dengan Bank Jateng meluncurkan sebuah aplikasi layanan pembayaran pajak secara online termasuk didalamnya pajak bea perolehan hak atas tanah dan bangunan. Layanan tersebut menjadikan wajib pajak, PPAT, dan petugas BKD tidak perlu bertatap muka langsung, guna mencegah adanya kebocoran yang selama ini di alami karena beberapa pihak melakukan suatu kerja sama agar pajak BPHTB yang di bayarkan menjadi murah meskipun tidak sesuai dengan harga transaksi yang terjadi di lapangan. Sistem pembayaran BPHTB secara online tersebut, di perkuat dengan adanya Peraturan Walikota Pekalongan Nomor 29 Tahun 2018 tentang pelaksanaan sistem online pajak daerah Pasal 2 huruf $f$ mengenai jenis pajak yang diatur oleh walikota yaitu BPHTB.

Sebelum Pelaksanaan E-BPHTB, para responden yang penulis simpulkan berpendapat bahwa pihak PPAT dalam pengurusan dan pembayaran BPHTB harus datang ke Kantor Badan Keuangan Daerah Kota Pekalongan, yangmana harus mengantri dan menunggu, sehingga menjadikan prosesnya menjadi lama dikarenakan harus pulang pergi apabila nilai yang diajukan tidak di terima oleh pihak BKD yang kemudian balik ke kantor PPAT lagi guna memanggil wajib pajak untuk mendiskusikannya kembali. Serta dalam sisi biaya PPAT 
harus mengeluarkan biaya untuk transportasi sehingga wajib pajak bayarnya menjadi lebih selain harus bayar BPHTB nya.

Berkaitan dengan pelaksanaan E-BPHTB terhadap jual beli hak atas tanah dan/atau bangunan yaitu pembayaran BPHTB secara online melalui website. Menurut penulis bahwa dalam peraturan walikota nomer 29 tahun 2018 tersebut tidak terdapat pasal yang berisi tentang yang dapat mengakses apakah hanya PPAT atau wajib pajak website E-BPHTB. Akan tetapi hanya orang yang sudah terdaftar saja yang bisa mengakses E-BPHTB ini, dalam hal ini yaitu hanya PPAT saja. Dilihat dari Peraturan Walikota Pekalongan Nomor 35 Tahun 2010 tentang Sistem dan Prosedur Pemungutan Bea Perolehan Hak Atas Tanah dan Bangunan, yang didalamnya berisi mengenai wajib pajak mengurus akta pemindahan hak atas tanah dan/atau bangunan melalui Pejabat Pembuat Akta Tanah (PPAT) atau Pejabat Lelang sesuai Peraturan Perundangan. Pejabat Pembuat Akta Tanah/Pejabat Lelang melakukan penelitian atas objek pajak yang haknya dialihkan. Wajib pajak menghitung dan mengisi Surat Setoran Pajak Daerah BPHTB yang disiapkan oleh Pejabat Pembuat Akta Tanah (PPAT). Berdasarkan aturan tersebut bisa dijadikan alasan mengapa hanya PPAT saja yang dapat mengakses masuk ke website E-BPHTB tersebut.

Hal tersebut diatas dibenarkan oleh Bapak Aminuddin S.H. yang mengatakan bahwa setiap notaris/PPAT diberikan nama akun beserta Password untuk dapat masuk ke website tersebut dan wajib pajak tidak bisa mengaksesnya serta dapat mendaftar bebas seperti membuat sebuah akun email. Berdasarkan hal tersebut wajib pajak tidak bisa mengurus pembayaran BPHTB secara mandiri dan harus dengan bantuan PPAT. Menurut penulis hal itu sudah jauh dari kata self assessment system, dimana wajib pajak diberi kepercayaan untuk menghitung dan membayar sendiri pajak yang terutang.

Terlepas dari wajib pajak yang tidak bisa mengurus pembayaran BPHTB nya sendiri, menurut Bapak Aminuddin SH mengatakan bahwa dengan adanya E-BPHTB ini PPAT sangat dimudahkan, lebih efisien waktu pengurusannya, tidak perlu datang antri ke Kantor BKD Kota Pekalongan. Selanjutnya mengutip dari pendapat dari Ibu Darosy Ernya Meigafatma S.H. yang mengatakan bahwa "Ya saya setuju dengan pendapat pak amin dan teman-teman notaris/PPAT lainnya bahwa dengan adanya E-BPHTB tersebut, kita merasa sangat dimudahkan karena tidak perlu capek-capek datang ke kantor BKD dengan membawa berkas dan tidak perlu mengantri terlalu lama guna menemui pihak terkait yang menangani BPHTB ini”. Dan ditambahkan lagi oleh Bapak Muhammad Sauki SH yang mengatakan bahwa "staf kita hanya menginput data data yang di perlukan ke dalam bentuk soft file, 
kemudian setelah itu setelah semua data terinput semua tinggal menunggu hasil verifikasi yang dilakukan oleh pihak BKD”.

Berdasarkan wawancara dengan beberapa notaris/PPAT di Kota Pekalongan, penulis menyimpulkan bahwa dalam pelaksanaan E-BPHTB para notaris/PPAT sangat dimudahkan dan menjadi cepat proses pembayaran BPHTB nya. Para notaris/PPAT tidak perlu datang langsung ke kantor BKD Kota Pekalongan dan mengantri lama serta terkadang harus bolak balik datang sampai semua selesai pembayarannya.

Menurut Bapak Aminuddin SH apabila perhitungan yang dilakukan oleh PPAT ditolak oleh pihak BKD Kota Pekalongan, PPAT harus menanyakan sebab perhitungan itu ditolak dan juga mengundang wajib pajak untuk mendiskusikan apakah wajib pajak bersedia dan menerima hasil verifikasi dari pihak BKD atau tidak serta dilakukan perhitungan kembali mendekati hasil verifikasi dari pihak BKD.

Akan tetapi Beliau juga menceritakan meskipun sudah mudah dengan adanya EBPHTB, apabila perhitungan tersebut ditolak padahal nilai transaksi yang di hitung sudah sesuai dengan aturan namun pihak BKD terkadang tidak percaya terhadap nilai transaksi tersebut. Beliau mencontohkan, ketika terjadi transaksi jual beli tanah senilai 2 miliar rupiah seharusnya pajak yang dibayarkan adalah 5 persen dari nilai transaksi. Namun pihak BKD terkadang tidak percaya dan menduga nilainya lebih dari itu. Sebagai PPAT kan tidak etis mengintrogasi penghadap (wajib pajak). Terkadang itu yang menjadi kendala PPAT dalam prosesnya.

Menurut Ibu Darosy, mengatakan bahwa dengan perhitungan yang otomatis itu membuat PPAT harus membicarakan dan bahkan membujuk wajib pajak untuk menyetujui nilai yang telah dikeluarkan oleh pihak BKD, karena apabila nilai yang telah di verifikasi tersebut di tolak terus menerus akan berakibat menjadi lama proses pembayarannya.

Berdasarkan pendapat para responden yang penulis rangkum, apabila proses verifikasi tidak kunjung selesai maka sangat merugikan para pihak dan satu hal yang paling fatal adalah jika salah satu pihak meninggal dunia sedangkan para pihak belum menandatangani akta PPAT sebagai bukti otentik atas peralihan hak tersebut. Hal tersebut akan menimbulkan permasalahan dikemudian hari terutama apabila ahli waris dari pihak yang meninggal tersebut tidak sepakat untuk melanjutkan perikatan tersebut. Dan bagaimana pula dengan uang penjualan yang telah diterima oleh pihak penjual dari pembeli apabila kesepakatan tersebut tidak dilanjutkan oleh ahli waris para pihak

Sedangkan Pelaksanaan E-BPHTB menurut BKD Kota Pekalongan sebagai penyedia layanan sistem pengurusan dan pembayaran BPHTB secara online. Menurut Kepala BKD 
Kota Pekalongan Bapak Doyok mengatakan bahwa E-BPHTB dalam pelaksanaannya lancar dan memudahkan tugas PPAT. Selain itu dengan adanya semua proses pembayaran BPHTB secara online tersebut, gunanya untuk mengurangi tatap muka secara langsung, agar tidak ada nego-nego nakal untuk mengakali harga pasar yang tidak sesuai dengan kenyataan dilapangan yang fungsinya agar pajak BPHTB yang dibayarkan menjadi lebih ringan.

Terkait dengan verifikasi lapangannya Bapak Doyok mengatakan bahwa untuk verifikasinya,BKD setiap tahun berdasarkan surat keputusan walikota menggunakan data Pajak Bumi dan Bangunan yang ditambahkan berapa persen atau dengan Zona Nilai Tanah milik Kantor Pertanahan yang kemudian di sesuaikan. Untuk besaran berapa persen angka penyesuaian nya itu menunggu surat keputusan walikota setiap tahunnya.

Berdasarkan hal tersebut penulis menyimpulkan bahwa self assessment system itu tetap terjadi walaupun dilakukan oleh pihak PPAT. E-BPHTB juga meringankan tugas dari PPAT serta untuk mengantisipasi tidak terjadinya kerja sama antar para pihak atau nego-nego nakal yang intinya agar pajak BPHTB yang dibayarkan menjadi murah tidak sesuai dengan nilai transaksi yang terjadi di lapangan. E-BPHTB ini berbeda dengan prosedur pembayaran secara konvensional dengan datang langsung ke kantor BKD dan tidak harus mengantri lama dengan kata lain lebih efisien waktu, tenaga,dan biaya. Selain itu juga menjukkan bahwa hasil verifikasi dari BKD susah untuk bisa dinego lagi dengan sebab karena wajib pajak terkadang tidak mencantumkan nilai transaksi yang riil, dan juga agar pendapatan pajak daerahnya meningkat, serta prosesnya juga menjadi semakin cepat. Akan tetapi BKD tetap menerima keberatan dari wajib pajak apabila perhitungannya dan surat keberatan yang dikirim secara online ditolak terus oleh pihak BKD, maka wajib pajak dipersilahkan datang sendiri ke kantor BKD Kota Pekalongan.

Pelaksanaan E-BPHTB terhadap jual beli hak atas tanah dan/atau bangunan dilihat dari pengamatan dan wawancara dengan beberapa narasumber memiliki kelebihan dan kekurangan tersediri dibanding secara konvensional. E-BPHTB ini memiliki kelebihan antara lain:

a. Lebih mudah dan ringan mengurusnya

b. Modern dan mengikuti kemajuan global

c. Lebih efisien terhadap waktu tidak perlu lama mengantri dikantor BKD

d. Lebih hemat biaya

e. Meminimalilir terjadi nya kecurangan yang dilakukan oleh wajib pajak dengan tidak mencantumkan nilai riil

Sedangkan kekurangan dari E-BPHTB antara lain:

a. Wajib pajak tidak bisa mengakses sendiri website tersebut 

b. nilai validasi yang tidak jelas patokannya
c. terkadang terjadi kesalahan terhadap sistemnya baik itu eror ataupun eror susah diakses

\section{Hambatan-hambatan apa yang timbul dari pelaksanaan E-BPHTB terhadap jual beli tanah dan bangunan di Kota Pekalongan}

Pada pelaksanaan E-BPHTB ini tentu saja tidak berjalan mulus, pasti terdapat hambatan-hambatan dalam prosesnya. Baik hambatan yang timbul di pihak Badan Keuangan Daerah Kota Pekalongan sebagai penyedia layanan dan yang mendapat mandat untuk melakukan pemungutan pajak Bea Perolehan Hak atas Tanah dan atau Bangunan sejak tahun 2010 sesuai dengan Peraturan Daerah Kota Pekalongan Nomor 8 Tahun 2010 Tentang Bea Perolehan Hak atas Tanah dan atau Bangunan, maupun pihak PPAT yang mewakili wajib pajak dalam proses pengurusan dan pembayaran BPHTB.

a. Hambatan-Hambatan yang terjadi pada BKD Kota Pekalongan

Pertama, Ada beberapa aturan pelaksanaan yang bisa dikatakan kurang mendetail sehingga menimbulkan kebingungan, salah satunya dalam hal Verifikasi lapangan, pihak BKD juga belum ada SKPD yang berkompeten dalam menilai nilai Objek Pajak yang terhutang BPHTB.

Kedua, terkait dengan data yang dimiliki sebagai penunjang BKD dalam menentukan nilai sebenarnya dari sebuah objek pajak BPHTB adalah Zona Nilai Tanah (ZNT) kota Pekalongan yang belum pernah diperbarui sejak tahun 2013. Dalam hal ini Zona Nilai Tanah untuk memudahkan proses penilaian yang dilakukan oleh BKD untuk itu ZNT harus selalu di update data dan data tersebut bisa diakses secara online sehingga masyarakat bisa memperoleh validitas data yang up to date tentang Zona Nilai Tanah sehingga masyarakat akan memperoleh haknya dan memperoleh kepastian hukum.

Ketiga, Masih adanya ketidakjujuran dari masyarakat dalam mencantumkan nilai transaksi jual beli tanah dan/atau bangunan, yang terkadang nilai transaksinya di kurangi yang fungsinya agar pembayaran BPHTB menjadi murah.

Keempat, data yang diberikan oleh Wajib Pajak mengenai objek pajak yang dilakukan proses pemindahan hak melalui jual beli yang menjadi piutang pajak BPHTB kerap tidak dinyatakan seperti yang sebenarnya, seperti lokasi tanah dan bangunan yang awalnya dilaporkan sebagai rumah gubuk dan tidak berada di bahu jalan atau tidak memiliki akses jalan padahal rumah tembok dan berada di bahu jalan raya, hambatan ini yang menyulitkan BKD kota Pekalongan dalam menilai pajak BPHTB terhutang sehingga kerapkali membutuhkan proses verifikasi lapangan. 
Kelima, Tidak seluruh SSPD BPHTB yang telah tervalidasi dibayar oleh wajib pajak, bahkan ada yang sudah melakukan pembayaran BPHTB namun wajib pajak batal melakukan peralihan hak sehingga wajib pajak memhon restitusi pajak BPHTB yang disetorkan, sedangkan UU No.28 Tahun 2009 belum mengatur mengenai restitusi pajak BPHTB.

b. Hambatan-hambatan yang dialami oleh pihak PPAT

Berdasarkan pengamatan dan wawancara yang dilakukan oleh penulis, merangkum apa saja hambatan-hambatan yang dialami oleh pihak PPAT dalam pelaksanaan E-BPHTB ini, antara lain:

Pertama, Patokan sebagai dasar pehitungan pembayaran BPHTB tidak jelas harus tiap tahunnya menunggu berdasarkan surat keputusan dari walikota Pekalongan yang terkadang tiap tahun berubah ubah sehingga menimbulkan kebingungan dalam proses perhitungannya serta kepastian hukumnya juga menjadi tidak jelas. Apabila patokan atau dasar yang jelas, pihak PPAT tidak berulang kali melakukan perhitungan terus menerus apabila ditolak oleh BKD Kota Pekalongan.

Kedua, hambatan yang sering dialami oleh PPAT adalah penghadap ataupun wajib pajak terkadang memberikan informasi tentang nilai transaksi yang tidak seseuai dengan nilai yang sebenarnya. Rata-rata para penghadap ini menginginkan pajak BPHTB ini menjadi lebih murah, itulah yang menjadikan PPAT memerlukan waktu untuk melakukan perhitungan apabila perhitunganmasih di tolak oleh pihak BKD Kota Pekalongan.

Ketiga, Harga pasar tanah dan/atau bangunan kurang transparan

Keempat, Apabila proses verifikasi tidak kunjung selesai maka sangat merugikan para pihak dan satu hal yang paling fatal adalah jika salah satu pihak meninggal dunia sedangkan para pihak belum menandatangani akta PPAT sebagai bukti otentik atas peralihan hak tersebut. Hal tersebut akan menimbulkan permasalahan dikemudian hari terutama apabila ahli waris dari pihak yang meninggal tersebut tidak sepakat untuk melanjutkan perikatan tersebut. Dan bagaimana pula dengan uang penjualan yang telah diterima oleh pihak penjual dari pembeli apabila kesepakatan tersebut tidak dilanjutkan oleh ahli waris para pihak

c. Hambatan-hambatan lainnya

Hambatan lainnya yang terjadi dalam pelaksaannya antara lain:

Pertama, website hanya bisa diakses dan yang dapat login adalah PPAT, bukan wajib pajak itu sendiri guna melakukan pembayaran BPHTB secara mandiri dan sesuai dengan Self Assessment System. 
Kedua, validasi yang dilakukan oleh pihak BKD dasar dan ukurannya tidak jelas apakah menggunakan ZNT dari BPN atau NJOP dari PBB.

Ketiga, dengan sistem online ini tidak selamanya lancar dalam mengaksesnya, terkadang sistem susah untuk diakses dan ataupun eror, serta diperlukan koneksi yang bagus guna kelancaran dalam mengaksesnya.

\section{Simpulan}

Pada Pelaksanaan E-BPHTB terhadap jual beli hak atas tanah dan/atau bangunan di Kota Pekalongan, pembayarannya dilakukan secara online melalui website https://bphtb.pekalongankota.go.id/ dengan dasar hukum Peraturan Walikota Pekalongan Nomor 29 Tahun 2018 tentang pelaksanaan sistem online pajak daerah Pasal 2 huruf f mengenai jenis pajak yang diatur oleh walikota yaitu BPHTB. Prosedur pembayaran BPHTB secara online memiliki beberapa langkah antara lain : Login, setiap PPAT yang terdaftar di BKD Kota Pekalongan diberikan akun beserta password nya untuk mengaksesnya; Pendaftaran digunakan untuk menginput data wajib pajak; Transaksi digunakan untuk mengisi data transaksi yang dilakukan oleh wajib pajak; Setelah proses diatas selesai kemudian cetak dan dilakukan pembayaran di bank terkait.

Menurut beberapa responden dalam pelaksanaanny E-BPHTB ini menjadi lebih cepat waktunya, mudah tanpa perlu datang langsung ke Kantor badan keuangan daerah untuk melakukan pengurusan, dan hemat biaya transportasi dan lain-lain, sedangkan sebelum adanya layanan ini pihak PPAT harus datang langsung ke kantor BKD untuk mengurus proses pemenuhan berkas, pembayaran serta keberatan terhadap nilai validasi yang di berikan oleh BKD sehingga memerlukan banyak waktu untuk mengantri, pulang pergi apabila nilai yang diberikan tidak sesuai dengan yang diajukan harus memanggil wajib pajak kembali, dan bnyak biaya yang dikeluarkan seperti transportasi, dan lain-lain.

Pada pelaksanaan E-BPHTB ini tentu saja tidak berjalan mulus, terdapat hambatanhambatan dalam prosesnya. Hambatan-hambatan tersebut yaitu :

a. Pada pihak BKD Kota Pekalongan hambatannya yaitu belum adanya aturan yang membahas secara mendetail mengenai nilai verifikasinya dan ketidakjujuran dari wajib pajak yang masih ada yang tidak memberikan nilai transaksi yang sesungguhnya.

b. Pada pihak PPAT di Kota Pekalongan hambatannya yaitu patokan sebagai dasar pehitungan pembayaran BPHTB tidak jelas harus tiap tahunnya menunggu berdasarkan surat keputusan dari walikota Pekalongan yang terkadang tiap tahun berubah ubah sehingga menimbulkan kebingungan dalam proses perhitungannya serta kepastian hukumnya juga menjadi tidak jelas dan nilai transaksi yang diberikan oleh wajib pajak masih ada yang tidak menunjukkan nilai 
yang sebenarnya dilapangan, serta proses nya menjadi lama apabila nilai yang diajukan ditolak oleh pihak BKD sehingga harus menghitung ulang kembali kemudian menunggu hasil verifikasinya.

c. Hambatan lainnya yang terjadi dalam pelaksaannya antara lain: website hanya bisa diakses dan yang dapat login adalah PPAT, validasi yang dilakukan oleh pihak BKD dasar dan ukurannya tidak jelas apakah menggunakan ZNT dari BPN atau NJOP dari PBB, dan dengan sistem online ini tidak selamanya lancar dalam mengaksesnya, terkadang sistem susah untuk diakses dan ataupun eror, serta diperlukan koneksi yang bagus guna kelancaran dalam mengaksesnya.

\section{DAFTAR PUSTAKA}

\section{Buku:}

Budiardjo, M. (2009). Dasar-dasar Ilmu Politik. Jakarta: PT. Gramedia Pustaka.

Cst Kansil, Christine, S.T Kansil, Engelien R, P. dan G. N. M. (2009). Kamus istilah hukum. Jakarta.

Islamy, I. (2000). Prinsip - Prinsip Perumusan Kebijaksanaan Negara. Jakarta: Bumi Aksara. Marzuki, P.M. (2008). Pengantar Ilmu Hukum. Jakarta: Kencana.

Rato, D. (2010). Filsafat Hukum Mencari: Memahami dan Memahami Hukum. Yogyakarta: Laksbang Pressindo.

Siahaan, M.P. (2003). Bea Perolehan Hak Atas Tanah Dan Bangunan Teori DanPraktek, Edisi 1. Jakarta: PT. RajaGrafindo Persada.

Soekanto, S. dan S. M. (1985). Penelitian Hukum Normatif SuatuTinjauan Singkat. Jakarta: Rajawali Pers.

Soemitro, R. H. (1988). Metode Penelitian Hukum dan Jurumetri. Jakarta: Alumni.

Sutedi, A. (2008). Hukum Pajak dan Retribusi Daerah. Bogor: Ghalia Indonesia.

Tangkilisan, H. N. (2003). Kebijakan Publik Yang Membumi. Yogyakarta: Lukman Offset.

Artikel Jurnal:

Ispriyarso, B. (2005). Aspek Perpajakan dalam Pengalihan Hak Atas Tanah dan/atau Bangunan karena Adanya Transaksi Jual Beli. Masalah-Masalah Hukum, 34, 277.

Widayat, A. W. (2016). Analisis Pengenaan Bea Perolehan Hak Atas Tanah Dan Bangunan Dalam Proses Jual Beli Tanah Dan Bangunan Di Kabupaten Kebumen. Jurnal Lex Renaissance. https://doi.org/10.20885/jlr.vol1.iss2.art3.

B. Ispriyarso, "Penggunaan Peraturan Bupati Untuk Mengatur Harga Tanah Dalam Pengenaan 
Bea Perolehan Hak Atas Tanah Dan Bangunan," Administrative Law \& Governance Journal, vol. 1, no. 4, pp. 363 -370, Dec. 2018. https://doi.org/10.14710/alj.v1i4.363 370

\section{Undang-undag dan Peraturan Perundang}

Undang-Undang Dasar Negara Republik Indonesia tahun 1945

Undang-Undang Nomor 20 Tahun 2000 tentang BPHTB

Undang-Undang Nomor 28 tahun 2009 tentang Pajak Daerah dan Retribusi Daerah

Undang-Undang Nomor 9 tahun 2015 tentang Otonomi Daerah.

Peraturan Daerah Kota Pekalongan Nomor 08 Tahun 2010 tentang BPHTB

Peraturan Walikota Nomor 35 Tahun 2010 tentang sistem dan prosedur pemungutan BPHTB

Peraturan Walikota Pekalongan Nomor 29 Tahun 2018 tentang pelaksanaan sistem online pajak 